\title{
A comparison of cardiovascular effects of dobutamine and isoprenaline after open heart surgery
}

\author{
Friedrich Kersting, ${ }^{1}$ Ferenc Follath, Robert Moulds, John Mucklow, Rory McCloy, \\ Joe Sheares, and Colin Dollery \\ From the Departments of Clinical Pharmacology and Surgery, Royal Postgraduate Medical School, Ducane \\ Road, London
}

In a cross-over study, the cardiovascular effects of dobutamine were assessed in 11 patients who had undergone operation for replacement of the mitral or aortic valve approximately four hours earlier. In 9 of these the effects of isoprenaline were assessed for comparison. Dose-resporse curves were obtained using four dose levels of dobutamine in the range 1.25-10 $\mathrm{\mu g} / \mathrm{kg}$ per min and of isoprenaline in the range of 0.005-0.04 $\mathrm{\mu g} / \mathrm{kg}$ per min. Both drugs produced similar dose-dependent increases in heart rate and cardiac output and a dosedependent decrease in peripheral resistance. Mean arterial pressure was only slightly increased by either drug. The positive inotropic effect of dobutamine was confirmed, but the chronotropic effect was not significantly different from that of isoprenaline. This contrasts with the firdings of previous studies, and possible reasons for this are discussed.

One of the most serious sequels of cardiac surgery is cardiovascular failure associated with low cardiac output (Dietzman et al., 1969). Isoprenaline is of benefit in this situation (Harrison, Kerber, and Alderman, 1970) but its use is often limited by the development of excessive tachycardia or of ventricular arrhythmias (Beregovich et al., 1971). The results of animal (McRitchie et al., 1973; Tuttle, 1974; Tuttle and Mills, 1975) and clinical studies in man (Jewitt et al., 1974) suggests that dobutamine, a novel sympathomimetic amine, has a lesser chronotropic effect than isoprenaline at doses equipotent in inotropic effect.

The purpose of the present clinical study was to compare the effects of dobutamine and isoprenaline on heart rate, cardiac output, and arterial pressure during the early postoperative period after heart valve replacement.

\section{Patients and methods}

Eleven patients ( 5 male, 6 female) aged 16 to 63 years (mean 40.1) were studied. All had undergone single valve replacement ( 6 aortic, 5 mitral) with either Starr-Edwards (7) or Bjork-Shiley (4) prosthesis. The effects of dobutamine and isopreReceived 16 December 1975.

In receipt of a grant from the Paul Martini Stiftung. naline were compared in 9 patients, the other 2 receiving dobutamine alone. Only those patients in sinus rhythm and free of other postoperative complications requiring continuous intensive treatment were included in the study. Patients in atrial fibrillation were excluded because dobutamine is known to shorten atrioventricular conduction time (Sinno et al., 1973). All were receiving intermittent positive-pressure respiration via endotracheal tube and had been sedated intravenously with diazepam and papaveretum (2.5 to $5.0 \mathrm{mg}$ of each). No other drugs had been given after operation. The study took place approximately four hours after the end of the operation and other intravenous infusions were interrupted during administration of dobutamine or isoprenaline.

Heart rate was determined by auscultation for one minute. Cardiac output was measured by the indicator dilution technique. Indocyanine green ( $5 \mathrm{mg}$ dissolved in $1 \mathrm{ml}$ saline) was injected through a pulmonary artery catheter inserted at the time of operation. Blood from a cannulated radial artery was pumped through a Gilford cuvette densitometer using a Harvard pump. Post-study calibration was performed with pooled blood. Duplicate control measurements of cardiac output differed by no more than 5.5 per cent. Blood pressure was measured using a Statham P23D transducer con- 
TABLE 1 Hamodynamic effects of dobutamine

\begin{tabular}{|c|c|c|c|c|c|c|}
\hline & & Control & $\begin{array}{l}1 \cdot 25 \mu \mathrm{\mu g} / \mathrm{kg} \\
\text { per min }\end{array}$ & $\begin{array}{l}2.5 \mu g / \mathrm{kg} \\
\text { per min }\end{array}$ & $\begin{array}{l}5 \cdot 0 \mu \mathrm{g} / \mathrm{kg} \\
\text { per min }\end{array}$ & $\begin{array}{l}10 \cdot 0 \mu g / \mathrm{kg} \\
\text { per min }\end{array}$ \\
\hline Heart rate (beats/min) & $\begin{array}{l}\text { Mean } \pm S E \\
\text { Per cent } \\
P\end{array}$ & $\begin{array}{l}\mathrm{n}=11 \\
99 \cdot 1 \pm 5 \cdot 2 \\
100\end{array}$ & $\begin{array}{l}\mathrm{n}=11 \\
102 \cdot 9 \pm 5 \cdot 4 \\
104 \\
<0.02\end{array}$ & $\begin{array}{l}n=11 \\
109 \cdot 1 \pm 6.7 \\
110 \\
<0.01\end{array}$ & $\begin{array}{l}n=11 \\
115.4 \pm 6.9 \\
116 \\
<0.005\end{array}$ & $\begin{array}{l}n=4 \\
124 \cdot 2 \pm 9 \cdot 8 \\
125 \\
<0.005\end{array}$ \\
\hline Cardiac output (l/min) & $\begin{array}{l}\text { Mean } \pm S E \\
\text { Per cent } \\
P\end{array}$ & $100^{3 \cdot 56 \pm 0.25}$ & $\begin{array}{l}3.97 \pm 0.26 \\
111 \\
<0.01\end{array}$ & $\begin{array}{l}4.39 \pm 0.29 \\
123 \\
<0.001\end{array}$ & $\begin{array}{l}5.03 \pm 0.32 \\
141 \\
<0.001\end{array}$ & $\begin{array}{l}6.68 \pm 0.61 \\
188 \\
<0.005\end{array}$ \\
\hline Cardiac index $\left(1 / \mathrm{min}\right.$ per $\left.\mathrm{m}^{2}\right)$ & $\begin{array}{l}\text { Mean } \pm S E \\
\text { Per cent } \\
P\end{array}$ & $100^{2 \cdot 19} \pm 0 \cdot 14$ & $\begin{array}{l}2.41 \pm 0.15 \\
110 \\
<0.01\end{array}$ & $\begin{array}{l}2.69 \pm 0.15 \\
123 \\
<0.001\end{array}$ & $\begin{array}{l}3.10 \pm 0.18 \\
142 \\
<0.001\end{array}$ & $\begin{array}{l}4.04 \pm 0.38 \\
184 \\
<0.001\end{array}$ \\
\hline Stroke volume $(\mathrm{ml})$ & $\begin{array}{l}\text { Mean } \pm S E \\
\text { Per cent } \\
\text { P }\end{array}$ & $\begin{array}{l}36 \cdot 4 \pm 2 \cdot 8 \\
100\end{array}$ & $\begin{array}{l}38 \cdot 6 \pm 3 \cdot 2 \\
106 \\
<0.05\end{array}$ & $\begin{array}{l}41.3 \pm 3.3 \\
113 \\
<0.005\end{array}$ & $\begin{array}{l}44 \cdot 7 \pm 3 \cdot 2 \\
123 \\
<0.001\end{array}$ & $\begin{array}{l}54 \cdot 1 \pm 3 \cdot 9 \\
149 \\
<0.025\end{array}$ \\
\hline Mean arterial pressure $(\mathrm{mmHg})$ & $\begin{array}{l}\text { Mean } \pm S E \\
\text { Per cent } \\
P\end{array}$ & $\begin{array}{l}82 \pm 4 \\
100\end{array}$ & $\begin{array}{l}84 \pm 4 \\
103 \\
\text { NS }\end{array}$ & $\begin{array}{l}87 \pm 4 \\
106 \\
<0.02\end{array}$ & $\begin{array}{l}89 \pm 4 \\
109 \\
<0.01\end{array}$ & $\begin{array}{l}86 \pm 10 \\
104 \\
<0.01\end{array}$ \\
\hline Systolic blood pressure (mmHg) & $\begin{array}{l}\text { Mean } \pm \text { SE } \\
\text { Per cent } \\
\mathbf{P}\end{array}$ & $\begin{array}{l}115 \pm 5 \\
100\end{array}$ & $\begin{array}{l}110 \pm 6 \\
104 \\
\text { NS }\end{array}$ & $\begin{array}{l}126 \pm 8 \\
110 \\
<0.02\end{array}$ & $\begin{array}{l}134 \pm 8 \\
115 \\
<0.005\end{array}$ & $\begin{array}{l}128 \pm 12 \\
111 \\
<0.01\end{array}$ \\
\hline Diastolic blood pressure (mmHg) & $\begin{array}{l}\text { Mean } \pm \text { SE } \\
\text { Per cent } \\
\text { P }\end{array}$ & $\begin{array}{c}66 \pm 4 \\
100\end{array}$ & $\begin{array}{l}67 \pm 3 \\
101 \\
\text { NS }\end{array}$ & $\begin{array}{l}67 \pm 3 \\
100 \\
\text { NS }\end{array}$ & $\begin{array}{l}68 \pm 4 \\
102 \\
\text { NS }\end{array}$ & $\begin{array}{l}65 \pm 9 \\
98 \\
\text { NS }\end{array}$ \\
\hline Systemic vascular resistance (units) & $\begin{array}{l}\text { Mean } \pm \text { SE } \\
\text { Per cent } \\
\text { P }\end{array}$ & $\begin{array}{l}25 \cdot 0 \pm 1 \cdot 5 \\
100\end{array}$ & $\begin{array}{l}22 \cdot 1 \pm 1 \cdot 5 \\
88 \\
<0.025\end{array}$ & $\begin{array}{l}20.7 \pm 1.4 \\
83 \\
<0.005\end{array}$ & $\begin{array}{l}18 \cdot 4 \pm 1 \cdot 2 \\
74 \\
<0.001\end{array}$ & $\begin{array}{l}12 \cdot 8 \pm 1 \cdot 1 \\
51 \\
<0.02\end{array}$ \\
\hline
\end{tabular}

TABLE 2 Haemodynamic effects of isoprenaline

\begin{tabular}{|c|c|c|c|c|c|c|}
\hline & & Control & $\begin{array}{l}0.005 \mu \mathrm{g} / \mathrm{kg} \\
\text { per min }\end{array}$ & $\begin{array}{l}0.01 \mu g / \mathrm{kg} \\
\text { per min }\end{array}$ & $\begin{array}{l}0.02 \mu g / k g \\
\text { per min }\end{array}$ & $\begin{array}{l}0.04 \mu g / k g \\
\text { per min }\end{array}$ \\
\hline Heart rate (beats/min) & $\begin{array}{l}\text { Mean } \pm S E \\
\text { Per cent } \\
\mathbf{P}\end{array}$ & $\begin{array}{l}n=9 \\
100 \cdot 0 \pm 5 \cdot 1 \\
100\end{array}$ & $\begin{array}{l}\mathrm{n}=6 \\
107 \cdot 2 \pm 7 \cdot 0 \\
107 \\
<0.05\end{array}$ & $\begin{array}{l}n=9 \\
111 \cdot 0 \pm 4.4 \\
111 \\
<0.005\end{array}$ & $\begin{array}{l}n=9 \\
118 \cdot 1 \pm 6 \cdot 0 \\
118 \\
<0.005\end{array}$ & $\begin{array}{l}\mathrm{n}=6 \\
122 \cdot 0 \pm 5.8 \\
122 \\
<0.001\end{array}$ \\
\hline Cardiac output (1/min) & $\begin{array}{l}\text { Mean } \pm S E \\
\text { Per cent } \\
\text { P }\end{array}$ & $100^{3 \cdot 6 \pm 0 \cdot 37}$ & $\begin{array}{l}4.59 \pm 0.52 \\
126 \\
<0.001\end{array}$ & $\begin{array}{l}4.75 \pm 0.41 \\
131 \\
<0.001\end{array}$ & $\begin{array}{l}5 \cdot 24 \pm 0.48 \\
144 \\
<0.01\end{array}$ & $\begin{array}{l}6.18 \pm 0.61 \\
170 \\
<0.001\end{array}$ \\
\hline Cardiac index $\left(1 / \min\right.$ per $\left.\mathrm{m}^{2}\right)$ & $\begin{array}{l}\text { Mean } \pm S E \\
\text { Per cent } \\
P\end{array}$ & $100^{2 \cdot 18 \pm 0 \cdot 23}$ & $\begin{array}{l}2.77 \pm 0.32 \\
127 \\
<0.005\end{array}$ & $\begin{array}{l}2.85 \pm 0.25 \\
131 \\
<0.001\end{array}$ & $\begin{array}{l}3.15 \pm 0.29 \\
144 \\
<0.001\end{array}$ & $\begin{array}{l}3.69 \pm 0.37 \\
169 \\
<0.001\end{array}$ \\
\hline Stroke volume $(\mathrm{ml})$ & $\begin{array}{l}\text { Mean } \pm \text { SE } \\
\text { Per cent } \\
\mathbf{P}\end{array}$ & $\begin{array}{l}36 \cdot 9 \pm 4 \cdot 0 \\
100\end{array}$ & $\begin{array}{l}43.4 \pm 5.0 \\
117 \\
<0.005\end{array}$ & $\begin{array}{l}43 \cdot 1 \pm 3.8 \\
117 \\
<0.001\end{array}$ & $\begin{array}{l}44 \cdot 9 \pm 4 \cdot 3 \\
122 \\
<0.001\end{array}$ & $\begin{array}{l}50 \cdot 1 \pm 4 \cdot 7 \\
136 \\
<0.01\end{array}$ \\
\hline Mean arterial pressure (mmHg) & $\begin{array}{l}\text { Mean } \pm \text { SE } \\
\text { Per cent } \\
\mathbf{P}\end{array}$ & $\frac{81 \pm 4}{100}$ & $\begin{array}{l}83 \pm 7 \\
102 \\
\text { NS }\end{array}$ & $\begin{array}{l}86 \pm 4 \\
107 \\
\text { NS }\end{array}$ & $\begin{array}{l}89 \pm 5 \\
109 \\
<0.02\end{array}$ & $\begin{array}{l}85 \pm 6 \\
104 \\
\text { NS }\end{array}$ \\
\hline Systolic blood pressure (mmHg) & $\begin{array}{l}\text { Mean } \pm S E \\
\text { Per cent } \\
P\end{array}$ & $\begin{array}{l}113 \pm 7 \\
100\end{array}$ & $\begin{array}{l}117 \pm 9 \\
102 \\
\text { NS }\end{array}$ & $\begin{array}{l}126 \pm 8 \\
111 \\
<0.05\end{array}$ & $\begin{array}{l}133 \pm 10 \\
117 \\
<0.02\end{array}$ & $\begin{array}{l}130 \pm 11 \\
115 \\
<0.005\end{array}$ \\
\hline Diastolic blood pressure (mmHg) & $\begin{array}{l}\text { Mean } \pm S E \\
\text { Per cent } \\
P\end{array}$ & $\begin{array}{c}63 \pm 4 \\
100\end{array}$ & $\begin{array}{l}66 \pm 6 \\
104 \\
\text { NS }\end{array}$ & $\begin{array}{l}66 \pm 3 \\
104 \\
\text { NS }\end{array}$ & $\begin{array}{l}68 \pm 4 \\
107 \\
\text { NS }\end{array}$ & $\begin{array}{l}63 \pm 6 \\
99 \\
\text { NS }\end{array}$ \\
\hline Systemic vascular resistance (units) & $\begin{array}{l}\text { Mean } \pm S E \\
\text { Per cent } \\
\text { P }\end{array}$ & $23 \cdot 5 \pm 2$ & $\begin{array}{l}19 \cdot 1 \pm 2 \cdot 5 \\
81 \\
\text { NS }\end{array}$ & $\begin{array}{l}19 \pm 1.7 \\
81 \\
<0.001\end{array}$ & $\begin{array}{l}17.9 \pm 1.71 \\
76 \\
<0.001\end{array}$ & $\begin{array}{l}14.6 \pm 1.9 \\
62 \\
<0.005\end{array}$ \\
\hline
\end{tabular}


nected to the radial artery cannula. Peripheral resistance was calculated by dividing mean arterial pressure by cardiac output.

Following duplicate baseline measurements, cumulative dose-response curves were obtained using four infusion rates of either isoprenaline in the range 0.005 to $0.04 \mu \mathrm{g} / \mathrm{kg}$ body weight per minute, or dobutamine in the range 1.25 to 10 $\mu \mathrm{g} / \mathrm{kg}$ body weight per minute. All measurements were repeated after five minutes at each dose-level and the infusion rates were then increased. Dobutamine was administered intravenously at infusion rates of $1.25,2.5$, and $5.0 \mu \mathrm{g} / \mathrm{kg}$ per min in 11 patients and at $10 \mu \mathrm{g} / \mathrm{kg}$ per min in 4 of these. In 2 patients the maximum dobutamine infusion rate of $10 \mu \mathrm{g} / \mathrm{kg}$ per min was maintained for 10 minutes. No difference was found between measurements made after 5 and after 10 minutes infusion, respectively. Isoprenaline was administered intravenously at infusion rates of 0.01 and $0.02 \mu \mathrm{g} / \mathrm{kg}$ per min in 9 patients and at 0.005 and $0.04 \mu \mathrm{g} / \mathrm{kg}$ per min in 6 of these. Isoprenaline and dobutamine infusions were separated by an interval of 30 minutes. Of the 9 patients who received both drugs, isoprenaline was given first in 4, dobutamine first in 5 . Both drugs were dissolved in 0.9 per cent sodium chloride solution and the total volume required to deliver each drug was 45 to $50 \mathrm{ml}$.

Statistical analysis using Student's paired and unpaired t-test or analysis of covariance for significance was applied appropriately to all values obtained.

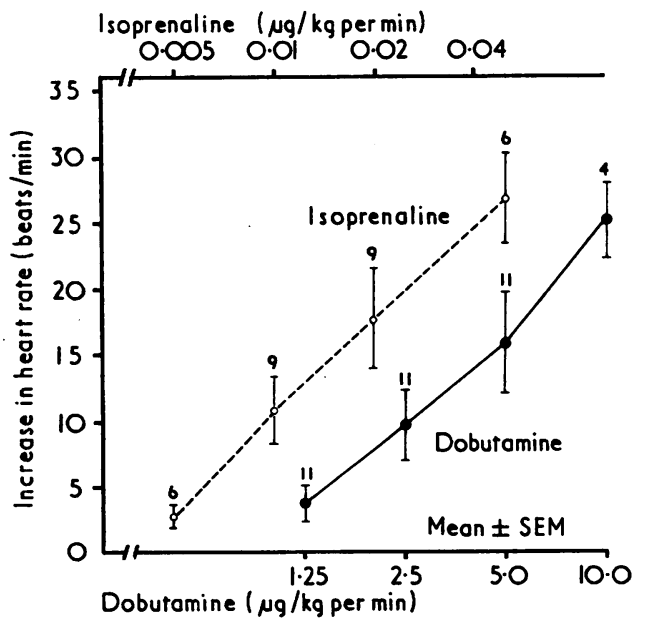

FIG. 1 Dose related changes in heart rate (number of cases for each mean is indicated).

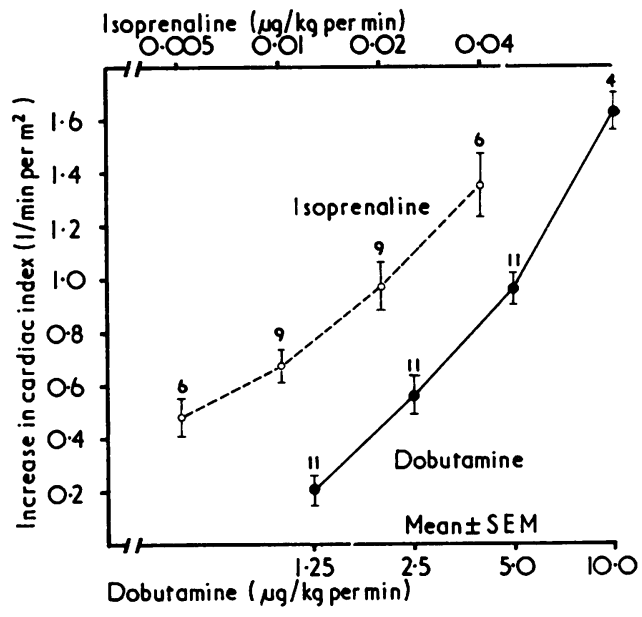

FIG. 2 Dose related changes in cardiac index (number of cases for each mean is indicated).

\section{Results}

The mean values for all measured and calculated parameters are shown in Tables 1 and 2 . The baseline values of all parameters were approximately the same regardless of which drug was given first. The initial cardiac index was between 1.56 and 2.46 $1 /$ min per $\mathrm{m}^{2}$ in all but one patient whose baseline value was $3.42 \mathrm{l} / \mathrm{min}$ per $\mathrm{m}^{2}$.

\section{Alteration in heart rate}

Both drugs caused a dose-dependent increase in heart rate (Fig. 1) and the slopes were similar. Even the lowest doses produced changes significantly different from the baseline values. The maximum isoprenaline dose of $0.04 \mu \mathrm{g} / \mathrm{kg}$ per min produced a mean increase of $27 \cdot 2 \pm 3.4$ beats per minute. In the 4 patients who received the maximum dobutamine dose of $10 \mu \mathrm{g} / \mathrm{kg}$ per min the mean increase was $25.5 \pm 2.9$ beats per minute.

\section{Alteration in cardiac index}

Both drugs caused a dose-dependent increase in cardiac index (Fig. 2). The effect of the lowest isoprenaline dose $\left(0.48 \pm 0.07 \mathrm{l} / \mathrm{min}\right.$ per $\left.\mathrm{m}^{2}\right)$ was significantly greater $(P<0.02)$ than that of the lowest dobutamine dose $\left(0.2 \pm 0.06 \mathrm{l} / \mathrm{min}\right.$ per $\left.\mathrm{m}^{2}\right)$. Further stepwise increase of dosage revealed no significant difference between the effects of isoprenaline and dobutamine. The maximum doses of both drugs caused increases of $1 \cdot 35 \pm 0.12$ (isoprenaline) and 1.62 \pm 0.07 (dobutamine) $1 / \mathrm{min}$ per $\mathrm{m}^{2}$. 


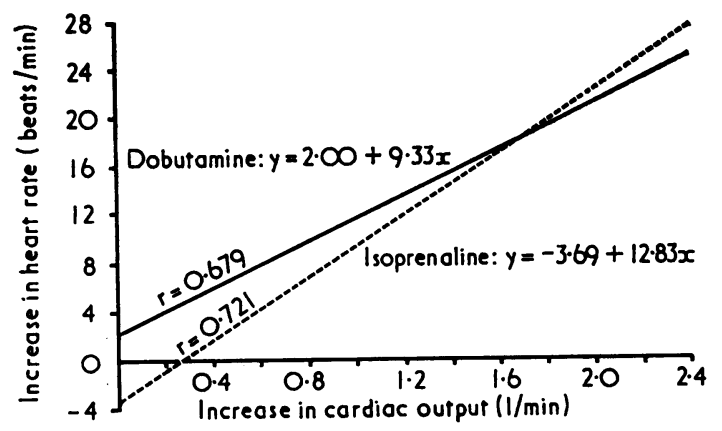

FIG. 3 Comparison between change in heart rate and change in cardiac output. Regression lines for dobutamine ( 37 observations) and isoprenaline (30 observations).

\section{Alterations in heart rate and cardiac output compared}

When alterations in heart rate were compared with alterations in cardiac output for each individual using linear regression lines (Fig. 3), analysis of covariance showed no significant difference between isoprenaline and dobutamine.

\section{Alteration in stroke volume \\ The lowest dose of isoprenaline caused an increase in stroke volume of $6.3 \pm 0.9 \mathrm{ml} /$ beat whereas the lowest dobutamine dose caused a significantly smaller $(P<0.02)$ increase of $2.0 \pm 0.7 \mathrm{ml} /$ beat. However, with further increase of dosage no signi- ficant difference between the effects of the two drugs could be shown.}

\section{Alteration in systemic arterial pressure and vascular resistance \\ Mean arterial pressure was slightly raised by both drugs. The maximal increase produced by isoprena- line was $8 \pm 2 \mathrm{mmHg}(1 \cdot 12 \pm 0.37 \mathrm{kPa})$ and this occurred at the dose level $0.02 \mu \mathrm{g} / \mathrm{kg}$ per min. Subsequent increase of dosage produced no further significant change. Dobutamine caused a steady dose-dependent increase of mean arterial pressure, the greatest being $9 \pm 1.5 \mathrm{mmHg}(1.26 \pm 0.2 \mathrm{kPa})$ at the dose level of $10 \mu \mathrm{g} / \mathrm{kg}$ per min. A dose- dependent decrease in peripheral resistance was produced by both drugs.}

\section{Development of arrhythmias}

The development of multiple ventricular ectopic beats in one patient receiving isoprenaline at 0.02 $\mu \mathrm{g} / \mathrm{kg}$ per min precluded further infusion. Earlier infusion of dobutamine in this patient had produced no arrhythmia. Monitoring of two patients throughout the study using an electrocardiograph tape- recorder showed that occurrence of arrhythmias was not significantly different when the two drugs were compared. In one of these patients, single ventricular ectopic beats occurred as frequently before infusion of either drug as they did during the infusion periods. (These data are insufficient to permit any valid comparison between the two drugs.)

\section{Side-effects}

Apart from drug-induced arrhythmias, no sideeffects were observed.

\section{Discussion}

The effects of dobutamine and isoprenaline upon heart rate, cardiac output, and blood pressure in the doses used were similar. These results alone are not sufficient to permit any firm conclusion about inotropic effect but there is other evidence to suggest that this can be inferred (Aktar, Chaudhry, and Cohn, 1973; Gunnar et al., 1973; Robie et al., 1974). The effect of dobutamine on cardiac output soon after open heart surgery resembles that observed by Beregovich et al. (1975) in patients with chronic congestive heart failure with similar low cardiac index (mean $2.1 \mathrm{l} / \mathrm{min}$ per $\mathrm{m}^{2}$ ). The lesser effect of dobutamine on heart rate, suggested by previous studies (Jewitt et al., 1974; McRitchie et al., 1973; Tuttle, 1974; Tuttle and Mills, 1975), could not be confirmed. There are several possible reasons for this finding.

First, in our study, we observed patients early in the postoperative period after open-heart surgery when cardiac output is maximally decreased (Rastelli and Kirklin, 1966). Previous clinical studies have involved patients with only moderate impairment of cardiac function. It is possible that the response to dobutamine differed because of the severe degree of functional impairment.

Secondly, augmented sympathetic activity is the rule after open-heart surgery and in congestive cardiac failure (Dietzman et al., 1969; Chidsey, Braunwald, and Morrow, 1965). Such augmentation may obscure the differential inotropic and chronotropic effects of dobutamine and isoprenaline.

Thirdly, all our patients had received intravenous papaveretum, and it is possible that concurrent administration of opiate influenced their response to dobutamine (and isoprenaline). Morphine alkaloids not only augment sympathetic activity (Hasbrouck, 1970) but also increase cardiac output and decrease peripheral resistance (Lowenstein et al., 1969).

In conclusion, though previous clinical studies suggested that dobutamine had haemodynamic advantages over isoprenaline, this is not so in patients 
with low cardiac output after open heart surgery when such a drug should have the greatest application. This study illustrates the importance of studying the clinical pharmacology of a drug in patients for whose treatment it has been designed.

We thank Dr. A. Glynne of the Lilly Research Centre for supplies of dobutamine and for advice and Miss A. Petrie for statistical help.

\section{References}

Aktar, N., Chaudhry, M. H., and Cohn, J. N. (1973). Dobutamine: selective inotropic action in patients with heart failure (abstract). Circulation, 48, Suppl. 4, 136.

Beregovich, J., Reicher-Reiss, H., Kunstadt, D., and Grishman, A. (1971). Hemodynamic effects of isoproterenol in cardiac surgery. Fournal of Thoracic and Cardiovascular Surgery, 62, 957.

Beregovich, J., Bianchi, C., D'Angelo, R., Diaz, R., and Rubler, S. (1975). Haemodynamic effects of a new inotropic agent (dobutamine) in chronic cardiac failure. British Heart fournal, 37, 629.

Chidsey, C. A., Braunwald, E., and Morrow, A. G. (1965). Catecholamine excretion and cardiac stores of norepinephrine in congestive heart failure. American fournal of Medicine, 39, 442.

Dietzman, R. H., Ersek, R. A., Lillehei, C. W., Castaneda, A. R., and Lillehei, R. C. (1969). Low output syndrome: recognition and treatment. fournal of Thoracic and Cardiovascular Surgery, 57, 138.

Gunnar, R. M., Loeb, H. S., Klodnycky, M., Sinno, M. Z., and Towne, W. (1973). Hemodynamic effects of dobutamine in man (abstract). Circulation, 48, Suppl. 4, 132.
Harrison, D. C., Kerber, R. E., and Alderman, E. L. (1970) Pharmacodynamics and clinical use of cardiovascular drugs after cardiac surgery. American fournal of Cardiology, 26, 385.

Hasbrouck, J. D. (1970). Morphine anesthesia for open-heart surgery. Annals of Thoracic Surgery, 10, 364.

Jewitt, D., Birkhead, J., Mitchell, A., and Dollery, C. (1974). Clinical cardiovascular pharmacology of dobutamine: a selective inotropic catecholamine. Lancet, 2, 363.

Lowenstein, E., Hallowell, P., Levine, F. H., Daggett, W. M., Austen, W. G., and Laver, M. B. (1969). Cardiovascular response to large doses of intravenous morphine in man. New England fournal of Medicine, 281, 1389.

McRitchie, R. J., Vatner, S. F., Tuttle, R., and Braunwald, E. (1973). Cardiovascular effects of dobutamine, a cardiospecific $\beta$ adrenergic stimulant in conscious dogs (abstract). Circulation, 48, Suppl. 4, 132.

Rastelli, G. C., and Kirklin, J. W. (1966). Hemodynamic state early after prosthetic replacement of mitral valve. Circulation, 34, 448.

Robie, N. W., Nutter, D. O., Moody, C., and McNay, J. L. (1974). In vivo analysis of adrenergic receptor activity of dobutamine. Circulation Research, 34, 663.

Sinno, M. Z., Loeb, H. S., Towne, W., and Gunnar, R. M. (1973). Electrophysiologic properties of dobutamine. Circulation, 48, Suppl. 4, 219.

Tuttle, R. R. (1974). The inotropic and chronotropic effects of dobutamine and isoproterenol on cat atria and papillary muscles at different temperatures. Federation Proceedings, 33, 503.

Tuttle, R. R., and Mills, J. (1975). Dobutamine: development of a new catecholamine to selectively increase cardiac contractility. Circulation Research, 36, 185.

Requests for reprints to Dr. F. Kersting, Department of Clinical Pharmacology, Royal Postgraduate Medical School, Ducane Road, London W12 0HS. 